\title{
PERAN SERTA STRATEGI SISTEM INFORMASI TERHADAP KEBERHASILAN PENERAPAN TEKNOLOGI INFORMASI PERUSAHAAN
}

\author{
Tanty Oktavia \\ Jurusan Sistem Informasi, Fakultas Ilmu Komputer, Universitas Bina Nusantara \\ Jl. KH. Syahdan No. 9, Palmerah, Jakarta Barat 11480. \\ tanty_oktavia@yahoo.com
}

\begin{abstract}
The role and strategy of information sytems in all business sectors that exist at present have a very important priority for the company. This is inevitable because the information system has become an important part in the continuity of a company. Perhaps without the information system, the company's operations will not be able to work properly because various sectors/divisions rely on business automation process. Planning strategy in an enterprise information system aims to enable companies to determine appropriate strategies in the information system implementation. Setting the information system and information technology strategically needs a way to understand the role of information technology on an organization. Most organizations will not hesitate to review the investment in information technology that has been done because the success of a company is also determined by the application of information systems. Evaluation of experience, success, and failure of the previous application is an important aspect in management strategy.
\end{abstract}

Keywords: strategy, sistem, information

\begin{abstract}
ABSTRAK
Peran serta strategi sistem informasi dalam seluruh sektor bisnis yang ada pada saat ini mendapat prioritas yang sangat penting bagi perusahaan. Hal ini tidak bisa dihindari lagi karena sistem informasi telah menjadi bagian penting dalam kelangsungan suatu perusahaan. Mungkin saja tanpa sistem informasi, operasional perusahaan tidak akan bisa berjalan sebagaimana mestinya karena berbagai sektor/divisi telah menggantungkan kepercayaan terhadap otomatisasi proses bisnis. Perencanaan strategi sistem informasi dalam suatu perusahaan bertujuan agar perusahaan dapat menentukan strategi yang tepat dalam penerapan sistem informasinya. Dalam mengatur sistem informasi dan teknologi informasi secara strategis diperlukan suatu cara untuk mengerti bagaimana peranan teknologi informasi terhadap suatu organisasi/perusahaan. Kebanyakan organisasi tidak akan ragu untuk memikirkan ulang investasi teknologi informasi yang telah dilakukannya karena keberhasilan suatu perusahaan juga ditentukan oleh penerapan sistem informasi. Evaluasi dari pengalaman, keberhasilan serta kegagalan penerapan sebelumnya merupakan aspek penting dalam manajemen strategi.
\end{abstract}

Kata kunci: strategi, sistem, informasi 


\section{PENDAHULUAN}

Persaingan global dalam dunia industri menuntut perusahaan saling berlomba-lomba meningkatkan kinerja di seluruh aspek bisnis yang ada. Keterlibatan sistem informasi dapat memberikan suatu kontribusi positif terhadap kemajuan pelaksanaan operasional perusahaan. Bentuk konkret dari hasil tersebut bisa dilihat secara nyata dari pengeluaran biaya, efisiensi yang dicapai, serta kepuasan seluruh pihak yang terlibat, baik pihak eksternal maupun internal. Struktur sistem informasi dalam suatu perusahaan terbagi atas pembagian aktifitas manajemen, di antaranya: (1) Perencanaan strategi. Aplikasi pada perencanaan strategik sangatlah krusial karena berperan dalam menentukan kesuksesan bisnis kedepannya, dimana harus bisa membuat dan mendukung perubahan dan bagaimana organisasi mengarahkan bisnis, dengan tujuan untuk mendatangkan keuntungan yang kompetitif; (2) Pengendalian manajemen. Fungsi aplikasi pada pengendalian manajemen adalah dapat memberikan dukungan dalam rangka meningkatkan efisiensi dan efektivitas bisnis; (3) Pengendalian operasional. Pada level ini aplikasi pendukung harus bisa mendukung operasional yang terjadi setiap hari dan dapat meminimalisasi kekurangan yang dapat merugikan pihak perusahaan.

Setiap tingkatan kegiatan manajemen memiliki aplikasi pendukung yang berbeda, seperti yang tercantum pada Gambar 1 di bawah ini.

Sistem informasi merupakan serangkaian ataupun gabungan dari komponen-komponen yang terlibat didalam suatu organisasi/perusahaan yang diharapkan dapat mendukung dalam menjalankan dan mengembangkan perusahaan. Hal ini dibahas secara jelas dalam bukunya Loudon \& Loudon (2006) yang mengungkapkan bahwa definisi sistem informasi adalah komponen yang berhubungan yang saling bekerja sama untuk mengumpulkan, memproses, menyimpan dan menyebarkan informasi yang mendukung pembuatan keputusan dan kontrol suatu organisasi. Hal ini diperkuat dengan pernyataan Bentley \& Whitten (2007) yang mengatakan bahwa sistem informasi adalah suatu kesatuan dari manusia, data, proses, dan teknologi informasi yang saling berinteraksi untuk mengumpulkan, memproses, menyimpan, dan menyediakan output informasi yang diperlukan untuk menunjang suatu organisasi.

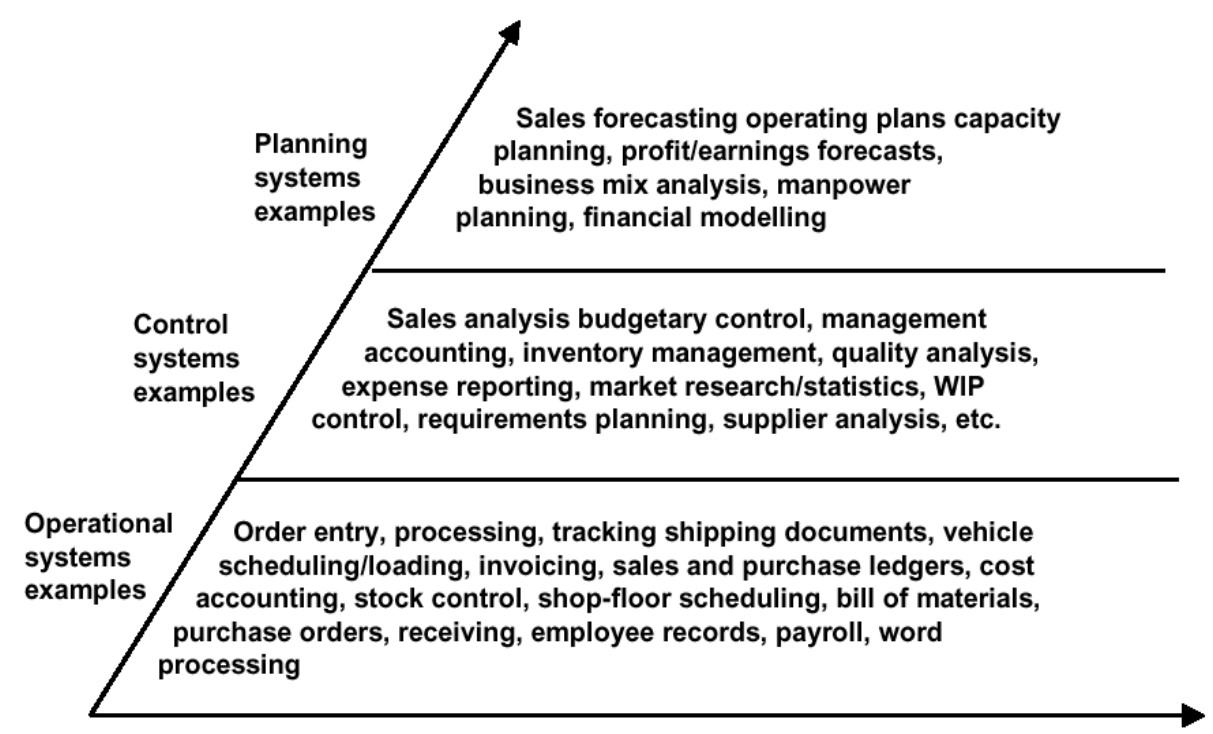

Gambar 1. Typical planning, control, and operational systems.

(Sumber: Ward \& Peppard, 2002) 
Definisi sistem informasi berbeda dengan definisi teknologi informasi, dimana teknologi informasi mengacu secara khusus pada teknologi, seperti hardware, software, dan jaringan telekomunikasi. Teknologi informasi memfasilitasi akuisisi, pemrosesan, penyimpanan, pengiriman, dan penyebaran informasi. Beberapa sistem informasi secara total bisa diotomatisasi dengan menggunakan teknologi informasi. Dengan cara ini, informasi dapat secara sempurna terhubung dan memenuhi seluruh permintaan yang ada secara real time.

Akuisisi suatu sistem informasi dalam suatu perusahaan/organisasi, bukanlah suatu masalah mudah karena sistem informasi merupakan bagian dari investasi perusahaan yang membutuhkan usaha yang cukup besar serta melibatkan beberapa aspek, seperti manusia, uang, waktu, dll. Diperlukan perumusan strategi yang tepat agar perumusan sistem informasi dapat tepat guna dan hasil yang diperoleh sesuai dengan tujuan yang diharapkan. Beberapa permasalahan yang mungkin timbul jika perumusan strategi perusahaan tidak sesuai di antaranya: (1) Hilangnya kesempatan bisnis. Sistem dan investasi teknologi yang diterapkan kadang kala tidak mendukung tujuan bisnis, bahkan menjadi batasan terhadap perkembangan bisnis; (2) Kurangnya integrasi sistem dan pengaturan informasi yang tidak efektif, informasi yang tidak akurat dan tidak memadai dalam menjalankan bisnis; (3) Prioritas yang tidak berdasarkan kebutuhan bisnis, level sumber daya yang tidak optimal, dan rencana proyek yang secara konsisten berubah, sehingga mengakibatkan performa bisnis yang tidak meningkat, biaya yang tinggi, solusi bisnis dengan kualitas dan produktifitas yang rendah; (4) Strategi teknologi yang kacau, pilihan yang tidak kompatibel, dan besarnya biaya yang dikeluarkan tidak sesuai. (5) Kurangnya pemahaman dan pengarahan di antara pengguna, manajemen senior dan IS/IT specialist dalam penanganan masalah, perumusan solusi, dan penyalahgunaan sumber daya.

Ward \& Peppard (2002, p.44) mengungkapkan bahwa strategi sistem informasi harus mampu memenuhi kebutuhan suatu organisasi atau kebutuhan atas informasi dan sistem untuk mendukung strategi bisnis suatu organisasi. Penyampaian informasi tidaklah mudah karena informasi haruslah dihasilkan dan disampaikan kepada mereka yang benar-benar membutuhkannya baik dari sisi waktu dan kegunaannya. Menurut Ward \& Peppard (2002, p.26) strategi sistem mempunyai empat karakteristik umum, yaitu: (1) Penyebaran informasi melalui sistem teknologi dengan customers, consumers, dan suppliers dan mengubah sifat hubungan; (2) Menghasilkan integrasi yang lebih efektif dari penggunaan informasi dalam proses penambahaan value perusahaan; (3) Memungkinkan suatu organisasi untuk mengembangkan, memproduksi, memasarkan, serta mengirimkan produk atau jasa baru berdasarkan informasi; (4) Menyediakan informasi bagi manajemen eksekutif guna mendukung pengembangan dan pelaksanaan strategi (khususnya di mana informasi eksternal dan internal yang relevan terintegrasi dalam analisis).

Tujuan utama mengembangkan strategi sistem informasi adalah untuk mengidentifikasi nilai tambah dari portofolio aplikasi yang akan meningkatkan performa suatu organisasi/perusahaan. Hal ini dapat diperoleh dengan menghubungkan kebutuhan sistem informasi pada strategi bisnis dengan eksplorasi kesempatan untuk IS/IT untuk membentuk strategi bisnis. Tujuan dari strategi IS/IT seharusnya tidak berfokus pada orientasi obyek, teknologi database, internet, HTML, spesifikasi hardware, atau end user karena seluruh aspek tersebut termasuk dalam permasalahan dalam implementasi. Ciri khas dari strategi sistem informasi harus sesuai dengan fokus bisnis, seperti meningkatkan pelayanan pelanggan, meningkatkan produktivitas atau menyediakan diferensiasi produk. Tantangan yang timbul dari tujuan tersebut adalah bagaimana mendefinisikan dan mengukur dampak strategi serta bagaimana relasi antara penyusunan strategi sistem informasi terhadap performa perusahaan.

Untuk mencapai keberhasilan strategi, perlu diperhatikan dan dianalisis faktor-faktor apa saja yang memungkinkannya. Ward \& Peppard (2003, p.35), mempunyai pendapat bahwa faktor keberhasilan dalam strategi sistem informasi, terdiri dari: (1) Fokus pada eksternal bukan internal: memperhatikan pelanggan, pesaing, supplier, bahkan bisnis lainnya, serta hubungan bisnis dan kesamaan dengan dunia bisnis di luar. Secara tradisional IS/IT difokuskan pada proses internal dan 
masalah-masalah yang ada; (2) Nilai tambah, bukan penurunan biaya: meskipun penurunan biaya yang mungkin bertambah disebabkan oleh ekspansi bisnis dengan biaya marginal berkurang. Hal ini konsisten dengan persyaratan perusahaan untuk membedakan diri dengan produk dan jasa pesaing yang lebih baik; (3) Berbagi keuntungan dalam suatu organisasi, dengan supplier, customer, consumer, dan juga competitor. Dalam beberapa kasus yang telah terjadi, tidak dilakukan pembagian keuntungan dalam suatu organisasi, tetapi keuntungan yang diperoleh digunakan untuk memperluas organisasi. Hal ini akan mengurangi keuntungan dan tidak memungkinkan untuk bertahan.

\section{METODE}

Dalam melakukan perencanaan strategi sistem informasi, Ward \& Peppard mengenalkan sebuah model yang dijabarkan pada Gambar 2 dibawah ini.

Input meliputi: (1) internal business environment - strategi bisnis saat ini, tujuan, sumber daya, proses, dan nilai budaya kerja; (2) external business environment - ekonomi, industri dan iklim persaingan dalam suatu organisasi; (3) the internal IS/IT environment - sudut pandang IS/IT dalam bisnis, tahap puncak, cakupan bisnis dan kontribusi, kemampuan, sumber daya dan infrastruktur teknologi; (4) the external IS/IT environment - trend teknologi dan peluang serta penggunaan IS/IT terutama bagi customers, competitors, dan suppliers.

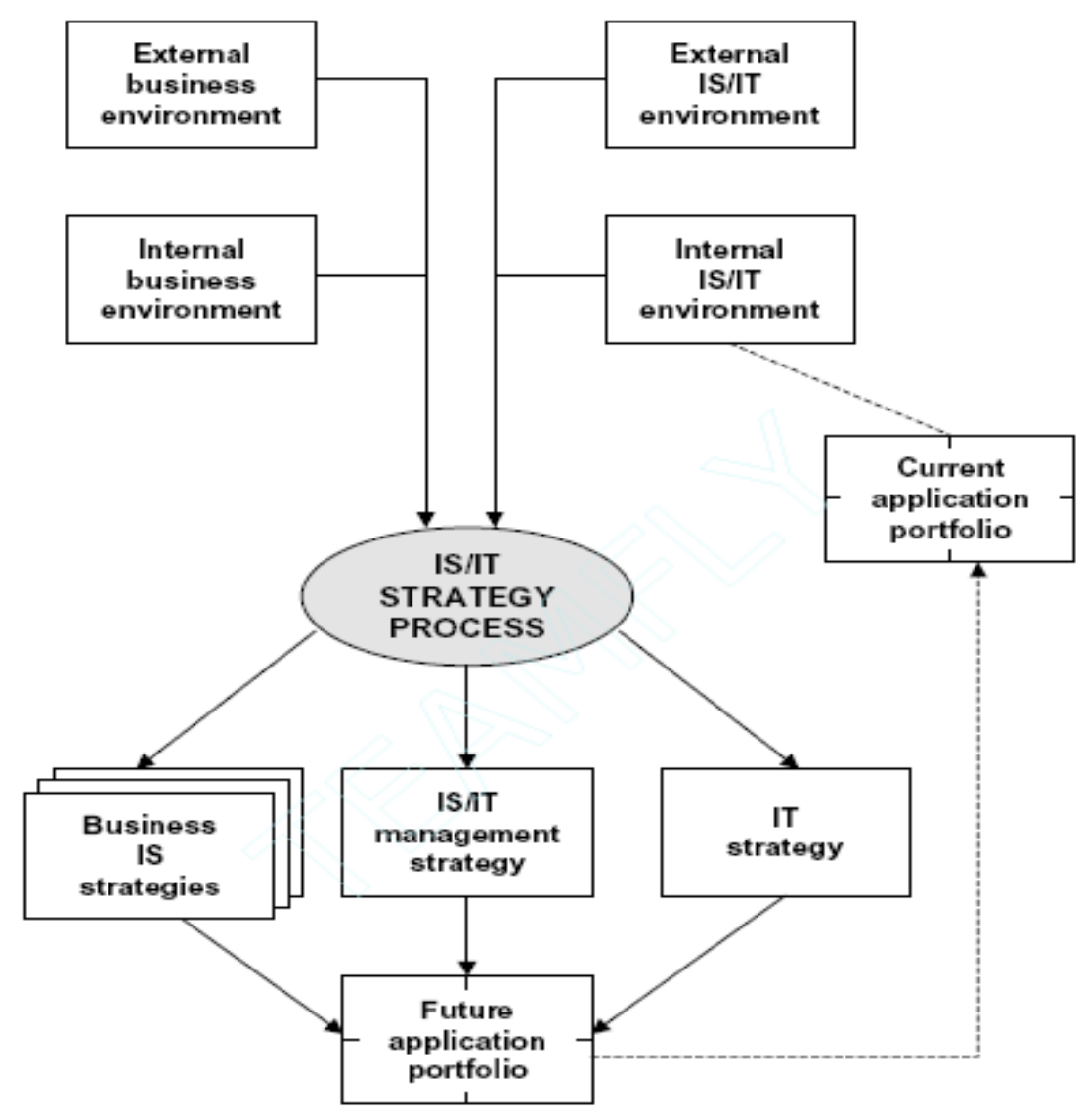

Gambar 2. Model penyusunan strategi IS/IT.

(Sumber: Ward \& Peppard, 2002, p.154) 
Output meliputi: (1) IS/IT strategi manajemen - aspek umum dari suatu strategi yang diterapkan organisasi, memastikan kebijakan yang konsisten jika diperlukan; (2) business IS strategies - bagaimana setiap unit akan menerapkan IS/IT untuk mencapai tujuan bisnis; (3) strategi IT kebijakan dan strategi untuk mengatur teknologi dan sumber daya ahli.

Model penyusunan perencanaan sistem informasi harus disesuaikan dengan strategi bisnis dan perencanaan strategi sistem informasinya. Adapun hubungan antara strategi bisnis dengan strategi sistem informasi dan teknologi informasi dapat dilihat pada Gambar 3 di bawah ini:

Selanjutnya, mengidentifikasi efek potensial pertama, kemudian mengevaluasi informasi dan sistem yang diperlukan untuk dihubungkan dengan strategi dan menentukan bagaimana cara memperoleh sistem informasi melalui teknologi. Dalam menentukan strategi IS/IT yang diharapkan dapat mendukung visi dan misi suatu organisasi, diperlukan suatu pemahaman yang mendalam mengenai strategi bisnis organisasi. Adapun pemahaman yang diperlukan, di antaranya: mengapa suatu bisnis dijalankan, kemana arah tujuan bisnis perusahaan, kapan target pencapain tujuan, bagaimana cara mencapai tujuan dan adakah perubahan yang perlu dilakukan. Oleh karena itu, perlu adanya penyelarasan seluruh aspek tersebut dengan strategi bisnis organisasi.

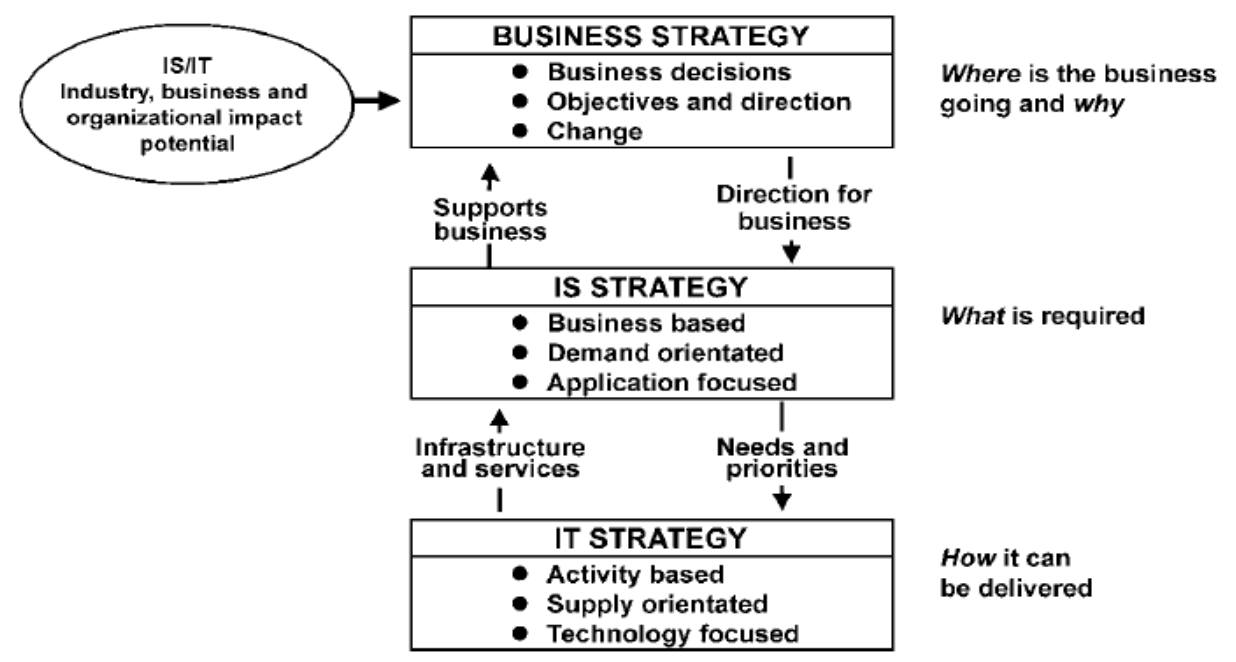

Gambar 3. Hubungan bisnis dengan strategi IS/IT.

(Sumber: Ward \& Peppard, 2002, p.41)

\section{HASIL DAN PEMBAHASAN}

\section{Peranan Strategi Sistem Informasi}

Kesadaran perusahaan terhadap penerapan strategi sistem informasi perlu dikembangkan secara luas dalam konteks suatu perusahaan dan perumusan strategi bisnis, serta proses pengimplementasiannya. Hal tersebut menjadi sangat penting dalam dekade terakhir, karena penerapan investasi yang dilakukan dalam sistem informasi dan teknologi selaras dengan pencapaian tujuan bisnis dan perencanaan. Peranan IS/IT tidak hanya sebagai alat pengimplementasi dari strategi yang dipilih, melainkan IS/IT juga dapat sebagai alat dalam perumusan suatu strategi bisnis yang baru. Sukses dalam pengaturan IS/IT, berarti memaksimalkan kembalinya hasil dari investasi yang dikeluarkan untuk menerapkan IS/IT dan memungkinkan strategi yang digunakan untuk memperoleh keuntungan kompetitif atau mengurangi rintangan kompetitif. 
Seluruh organisasi/perusahaan memiliki beberapa bentuk strategi, baik secara implisit maupun eksplisit, di mana inti dari strategi bisnis tersebut adalah menciptakan keunggulan kompetitif yang lebih cepat dari pesaingnya. Evolusi strategi dan strategi planning suatu perusahaan dikembangkan dalam suatu model untuk menjelaskan peningkatan suatu perusahaan (Gambar 4). Meskipun terdapat beberapa perubahan, sejak tahun 1980 model ini sudah bisa menggambarkan bagaimana inti permasalahan yang terlibat, sejalan dengan pendekatan untuk mengembangkan dan mengimplementasikan strategi. Pada fase pertama perusahaan berfokus pada aliran kas dan perencanaan keuangan tahunan dan melibatkan beberapa teknik sederhana untuk mengembangkan medium-term budgets. Sedangkan pada fase kedua, difokuskan pada percobaan prediksi - meramalkan apa yang mungkin terjadi pada tiga atau empat tahun ke depan. Hal ini bisa dilakukan dengan mengacu pada historical performance, analisis dan proyeksi ke depan menggunakan internal trend dan parameter eksternal, seperti ekonomi dan riset data pasar yang bisa meramalkan penjualan dan perkembangan pasar serta memprediksi efek terhadap pemasukkan dan biaya. Pada fase ketiga, organisasi untuk pertama kalinya mengharapkan eksternal untuk memperoleh keuntungan melalui pemahaman terhadap nature dari persaingan dalam industrinya, dengan menilai dan sadar terhadap rintangan potensial serta posisi perusahaan untuk memperoleh keuntungan kompetitif. Organisasi harus merevisi portofolio produk untuk menyesuaikan dengan permintaan dalam sektor pasar yang lebih atraktif, atau meningkatan nilai/fitur pada produk dan servis, atau dengan mengurangi biaya produksi. Sedangkan pada fase keempat, organisasi diarahkan pada inovasi dan berubah menjadi organisasi yang mampu membentuk lingkup bisnisnya sendiri. Organisasi harus mampu merespon perubahan pasar dari sisi produk baru dan persaingan yang ketat. Nilai suatu organisasi, budaya dan struktur harus bisa mendorong proses dan kompetensi yang dibutuhkan untuk berkembang dan menjadi pimpinan dalam industri. Untuk tetap bisa menjadi pemimpin dalam pasar diperlukan inovasi secara berkelanjutan. Ketika beberapa organisasi mampu membentuk strategi yang kreatif, perlu juga dilakukan pengawasan terhadap keadaan lingkungan sekitar.

Pada dasarnya suatu strategi IS/IT terbagi menjadi dua bagian, yaitu komponen sistem informasi dan komponen teknologi informasi. Strategi sistem informasi mendefinisikan kebutuhan organisasi atau permintaan akan informasi dan sistem untuk mendukung keseluruhan strategi bisnis dalam perusahaan. Dalam menghadapi persaingan bisnis perlu disadari kebutuhan IS/IT yang dapat memberikan pengaruh secara kompetitif. Dengan begitu perlu dilakukan pengukuran prioritas invetasi yang dibutuhkan untuk mencapai suatu portofolio aplikasi yang ideal, keuntungan yang diharapkan, serta perubahan yang dibutuhkan untuk mengaplikasikan hal tersebut, termasuk batasan sumber daya dan kebebasan suatu sistem. Sedangkan IT strategi lebih berfokus pada bagaimana permintaan suatu organisasi/perusahaan terhadap informasi dan sistem dapat didukung oleh bantuan teknologi. Lebih cenderung pada IT Supply yang melibatkan kemampuan IT dan sumber daya yang ada (seperti hardware, software, dan telekomunikasi) dan layanan jasa. IS strategi dan IT strategi memiliki peranan yang sangat penting, jika tidak didukung oleh dua hal tersebut akan berakibat fatal terhadap beberapa aspek, di antaranya: (1) Investasi sistem yang telah dibuat tidak dapat mendukung tujuan bisnis; (2) Hilangnya kontrol terhadap IS/IT, sehingga masing-masing individu menjalankan kemauannya sendiri-sendiri yang mengakibatkan IS/IT menjadi tidak kompatibel dengan tujuan awalnya; (3) Tidak terintegrasinya sistem yang bisa mengakibatkan duplikasi pengerjaan dan informasi yang dihasilkan menjadi tidak akurat lagi; (4) Tidak adanya pengaturan prioritas terhadap sistem informasi projek maupun sumber daya, yang bisa berdampak pada penurunan produktivitas, dll.; (5) Tidak ada mekanisme untuk menentukan level sumber daya yang optimal atau pengoperasian sistem yang maksimal; (6) Pengaturan informasi yang kurang mendukung, seperti tidak tersedia, tidak konsisten, tidak akurat, atau terlalu lama; (7) Kesalahpahaman antara pengguna dan IT specialist yang mengakibatkan konflik dan ketidakpuasan dari masing-masing pihak; (8) Tidak sesuainya strategi teknologi dengan batasan yang ada; (9) Kurangnya investasi infrastruktur yang terbentuk; (10) Seluruh proyek dievaluasi dari sisi keuangan saja; (11) Masalah yang timbul dalam investasi IS/IT dapat menjadi sumber permasalahan di antara bagian dalam perusahaan. 


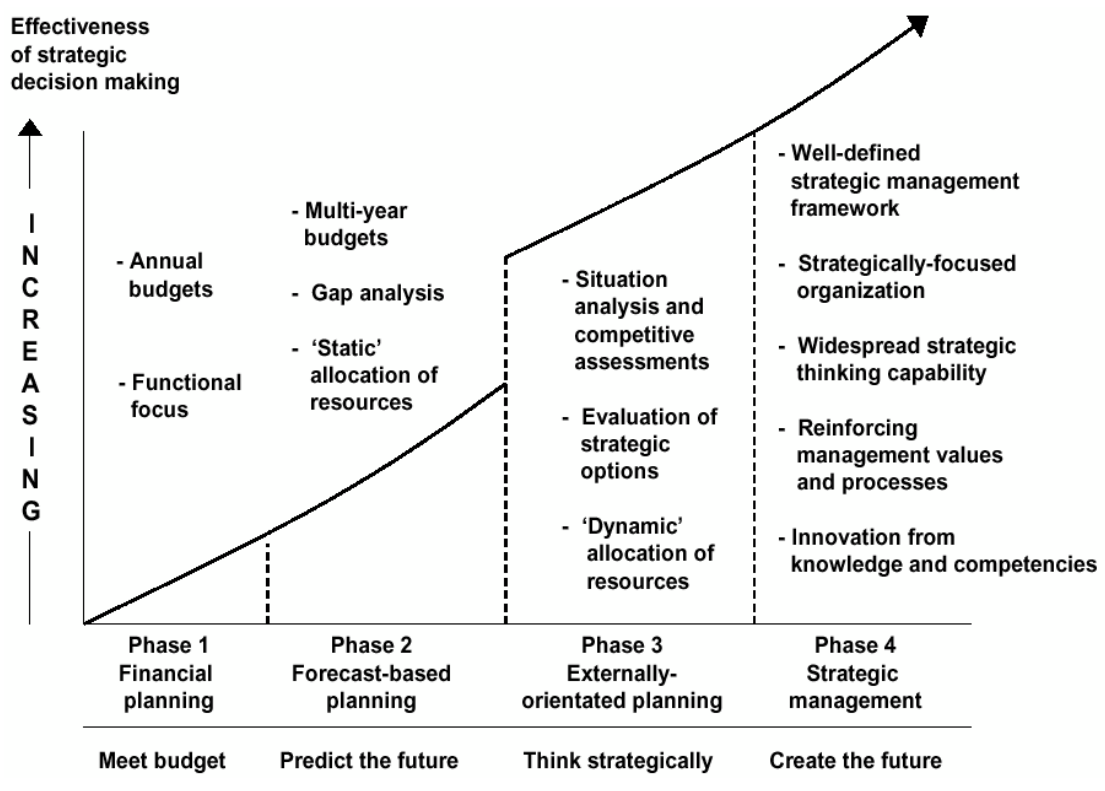

Gambar 4. Evolution of strategic management maturity.

(Sumber: Ward \& Peppard, 2002, p.66)

\section{Rumusan Permasalahan}

Dalam dekade sebelumnya beberapa organisasi telah mengembangkan secara sempurna strategi sistem informasi tapi tidak bisa berjalan sempurna karena tidak memiliki komitmen pengaturan terhadap sistem yang diinvestasikan. Mereka tidak pernah berharap IS/IT bisa membantu mereka dalam mencapai keuntungan bisnis. Beberapa permasalahan yang timbul, di antaranya: (1) Top manajer kurang menyadari dampak positif yang diperoleh dari penerapan IS/IT terhadap keuntungan strategis. Mereka lebih cenderung melihat IS/IT murni sebagai suatu komputer yang digunakan untuk mendukung operasional; (2) Terkadang penerapan IT tidak semudah yang dibayangkan karena penerapannya bagi sebagian orang akan mempersulit suatu organisasi dalam mencapai keuntungan yang diharapkan; (3) Top manajer tidak melihat informasi yang dihasilkan sebagai sumber daya bisnis untuk diatur untuk mencapai keuntungan jangka panjang; (4) Sulitnya melihat kelebihan penerapan IS, top manajer hanya melihat dari sisi keuangan untuk investasi; (5) Top manajer cenderung berorientasi pada fokus jangka pendek daripada rencana jangka panjang, khususnya untuk penerapan IS/IT.

Organisasi/perusahaan lebih berfokus pada investigasi kebutuhan bisnis dan prioritas yang mengarahkan strategi bisnis dan tujuan, yang dibentuk oleh anggota tim bisnis, namun ketika dilakukan realisasi strategi secara efektif dan berdasarkan dengan perencanaan, jarang sekali perusahaan yang dapat mengkonsolidasi dan mengatur pengintegrasian program bisnis dalam jangkauan yang luas.

\section{Kerangka Kerja Strategis}

Beberapa teknik analisis perumusan strategi dibutuhkan untuk berfokus pada permasalahan strategi yang ada, seperti analisis pesaing, keunggulan portofolio produk, atau hubungan dari beberapa aspek terhadap pengambilan keputusan. Meskipun demikian, terdapat konteks yang luas dalam teknik dan tool yang digunakan, dengan kata lain sebagai kerangka kerja strategis. 
Kerangka kerja melibatkan beberapa faktor dalam pengaturan strategi bisnis yang terbagi menjadi tiga layer, yaitu: lingkungan eksternal, tekanan kelompok (pemegang saham, kompetitor, pelanggan, karyawan, pemerintah, dll. ), dan stakeholders, strategi bisnis internal dan perencanaan. Setelah mengetahui faktor yang perlu diperhatikan dari lingkungan eksternal dan ancaman serta kesempatan yang diperoleh dari tekanan kelompok, organisasi/perusahaan harus mengidentifikasi, mengevaluasi, dan menentukan strategi yang tepat untuk mencapai tujuan bisnis dengan perencanaan dan penggunaan sumber daya yang efektif. Kunci masalah dalam beberapa proses strategi adalah menentukan lingkup. Apakah bisa mencakup keseluruhan perusahaan atau hanya bagian kecil saja? Menganalisis strategi bisnis memerlukan beberapa tuntutan, di antaranya: (1) Mengidentifikasi strategi yang digunakan saat ini dan sebelumnya, (2) Mengintepretasikan dan menganalisis strategi, dan menggambarkan struktur metode, (3) Menyusun dan mengkonfirmasi kebutuhan IS. Berikut contoh kerangka kerja strategi bisnis yang terintegrasi menurut Ward \& Peppard (2002, Gambar 5).

\section{Teknik Interpretasi dan Analisis}

Analisis situasi dan strategi bisnis dapat dilakukan dalam beberapa teknik, di antaranya seperti yang terdapat pada tabel 1 :

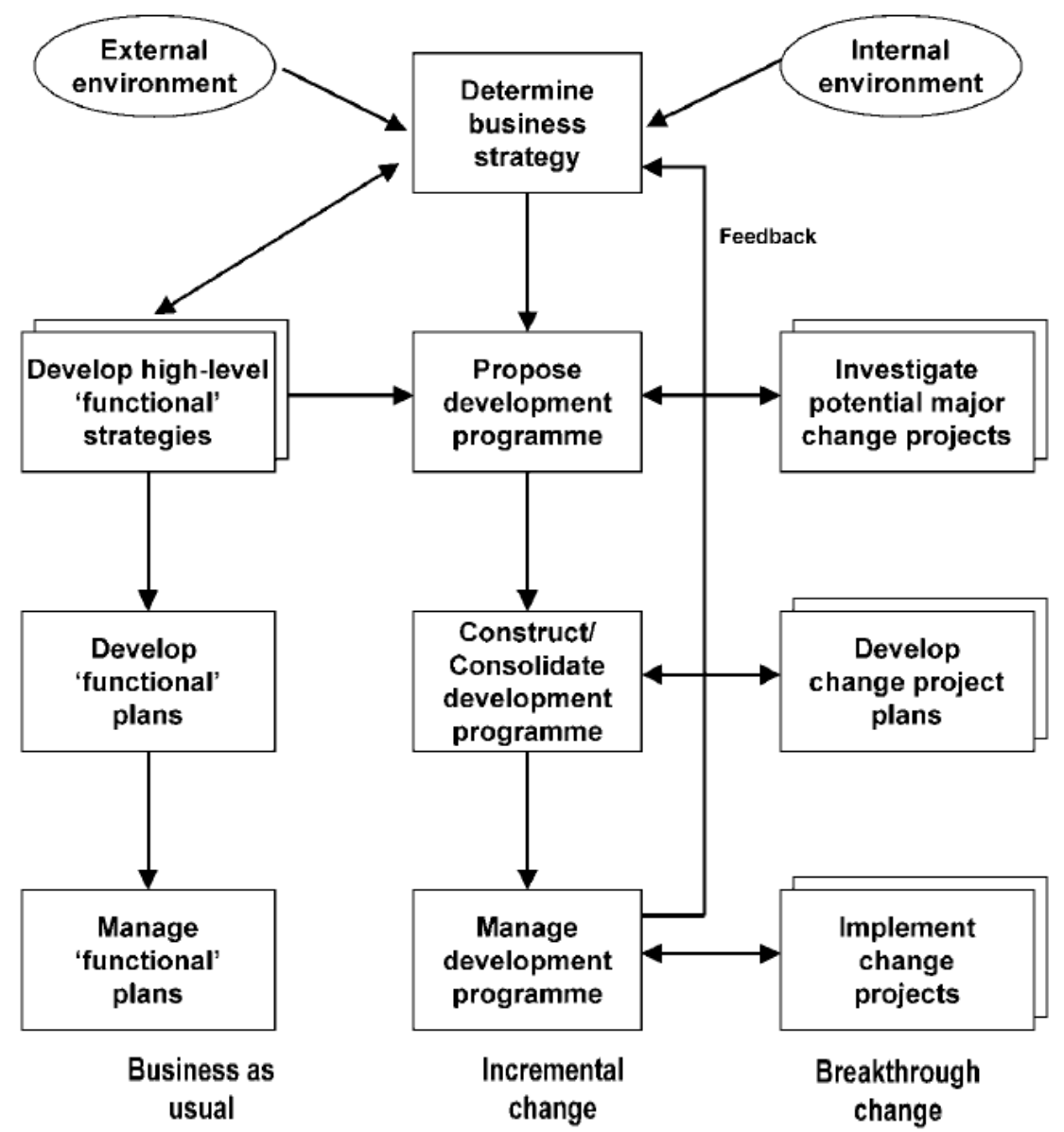

Gambar 5. Integrated business strategy framework.

(Sumber: Ward \& Peppard, 2002, p.133) 
Tabel 1

Teknik Pengidentifikasian Kebutuhan IS

\begin{tabular}{|c|c|}
\hline Technique & Deliverables \\
\hline Business strategy analysis & $\begin{array}{c}\text { Business strategy mission, objectives, etc } \\
\text { Global business initiatives } \\
\text { Business area initiatives } \\
\text { Business priorities } \\
\text { IS requirements leading to IS demand }\end{array}$ \\
\hline Critical Success Factor (CSF) analysis & $\begin{array}{l}\text { Areas of business activity 'where things must go right' } \\
\text { Potential IS/IT thrusts } \\
\text { Performance measures }\end{array}$ \\
\hline SWOT analysis & $\begin{array}{l}\text { Analysis of Strength, Weakness, Opportunities, and Threats of internal and } \\
\text { external business and IS/IT environments }\end{array}$ \\
\hline Balanced Scorecard analysis & $\begin{array}{l}\text { Business objectives and key information requirements } \\
\text { Performance measures }\end{array}$ \\
\hline $\begin{array}{l}\text { Business portfolio and competitive } \\
\text { strategy analysis }\end{array}$ & Option for long term IS investment to strengthen competitive position \\
\hline $\begin{array}{l}\text { Value chain analysis (internal and } \\
\text { external) }\end{array}$ & $\begin{array}{c}\text { Internal information flows } \\
\text { High level 'industry' information flow model } \\
\text { Potential impact of IS/IT }\end{array}$ \\
\hline $\begin{array}{l}\text { Process analysis/Business process re- } \\
\text { engineering }\end{array}$ & $\begin{array}{l}\text { Identification of core business process } \\
\text { Effectiveness of processes in meeting drivers } \\
\text { Process improvement options } \\
\text { Process redesign blueprints (that deliver significant performance improvement } \\
\text { regarding drivers) } \\
\text { Resultant IS/IT options }\end{array}$ \\
\hline Organizational modeling & $\begin{array}{l}\text { Comprehensive assessment of the business and IS/IT environments } \\
\text { Filtering mechanism in assessing options for change }\end{array}$ \\
\hline $\begin{array}{l}\text { Business modeling information } \\
\text { analysis techniques }\end{array}$ & $\begin{array}{l}\text { Enterprise model : } \\
\text { entity models } \\
\text { object models } \\
\text { process dependency charts } \\
\text { data flow diagrams } \\
\text { functional decomposition diagrams } \\
\text { conceptual architecture }\end{array}$ \\
\hline Current portfolio evaluation & $\begin{array}{l}\text { Profile of current applications } \\
\text { Coverage and contribution to business user and technical satisfaction } \\
\text { Contribution of applications to business strategy }\end{array}$ \\
\hline $\begin{array}{l}\text { Technology assessment and IS/IT } \\
\text { infrastructure review }\end{array}$ & $\begin{array}{c}\text { Inventory of current hardware and software } \\
\text { Assesment of IS organization, procedures, skills, and methods }\end{array}$ \\
\hline
\end{tabular}

(Sumber: Ward \& Peppard, 2002, p.205)

\section{Pengukuran dan Manajemen Resiko Investasi}

Sebagai bagian dari penilaian suatu investasi, diperlukan pengukuran resiko potensial yang mungkin terjadi, baik resiko yang bersifat umum, maupun resiko yang timbul dalam rangka mencapai keuntungan yang diharapkan. Beberapa resiko kesalahan yang mungkin bisa terjadi di antaranya: (1) Kesalahan teknis - masalah ini berkaitan dengan penggunaan IT, yang bertanggung jawab terhadap kualitas sistem dan teknologi yang digunakan; (2) Kesalahan data - masalah ini melibatkan dua pihak, yaitu pihak IS/IT dan pihak pengguna yang menginput data. Secara jelas, design yang baik, integritas pemrosesan, dan pengaturan data merupakan bagian dari sistem informasi, tapi tidak semua hal tersebut bisa menjadi tanggung jawab seorang IS specialist; (3) Kesalahan pengguna - beberapa permasalahan teknis yang terjadi sering kali menjadi kesalahan bagian IS/IT. Untuk mengurangi 
permasalahan tersebut perlu dilakukan pelatihan penggunaan aplikasi terhadap pengguna, sehingga memiliki kapabilitas dalam menjalankan sistem. Penyebab utama dalam faktor ini adalah sebagian besar karena kurangnya pelatihan dan operasional sistem kurang efektif karena penggunaan melebihi batas waktu; (4) Kesalahan organisasi - penerapan aplikasi pada suatu organisasi bisa berefek sukses ataupun gagal dalam memuaskan kebutuhan organisasi secara keseluruhan. Sebagai contoh, sistem kontrol bujet dibuat bagi akuntan, namun aplikasi tersebut bisa saja gagal dalam memenuhi kebutuhan manajer lini untuk merancang dan mengontrol tipe pengeluaran bisnis yang berbeda. Tanggung jawab secara jelas dimana IS/IT harus bisa memenuhi seluruh kebutuhan dalam organisasi; (5) Kesalahan dalam lingkungan bisnis - sistem harus bisa memenuhi kebutuhan eksternal atau internal.

Tujuan dilakukannya pengukuran resiko adalah untuk meningkatkan peluang sukses, tapi dalam penerapannya manajemen perlu mengerti hubungan antara resiko dari seluruh pengembangan portofolio. Dengan demikian, resiko strategis, key operational, dan aplikasi pendukung harus dibandingkan.

\section{PENUTUP}

Sistem informasi selalu menjadi bagian dalam proses peningkatan value suatu perusahaan, baik perusahaan komersial, perusahaan jasa umum atau sosial yang difokuskan pada: operasi internal dan kontrol, kunci proses organisasi, dan faktor sukses internal. Dalam mengembangkan strategi IS/IT diperlukan pemikiran secara strategis dan perencanaan secara jangka panjang dan optimal pada semua faktor yang terlibat. Salah satu cara yang dapat dilakukan adalah memahami situasi bisnis saat ini dan merumuskan kebutuhan sistem informasi yang saling terkait dengan strategi bisnis untuk mencapai tingkatan yang lebih tinggi. Hubungan antara strategi dan perencanaan IS/IT terhadap tujuan dan strategi seluruh unit bisnis perusahaan sangatlah vital. Bahkan pada beberapa kasus yang saat ini terjadi, perumusan strategi IS/IT dan perencanaan dilakukan bersamaan dengan proses perumusan strategi dan perencanaan perusahaan, sehingga seluruh proses strategi bisa terintegrasi. Setiap tool ataupun teknik yang digunakan dalam proses pengembangan strategi dan perencanaan harus memiliki relevansi terhadap strategi IS/IT yang dirumuskan, sehingga memungkinkan manajer secara positif aktif terlibat. Sejak aplikasi memiliki kontribusi yang berbeda terhadap bisnis, seperti yang dijelaskan dalam portofolio aplikasi, suatu aplikasi perlu untuk dinilai dengan cara yang berbeda. Pendekatan ini memerlukan pengaturan prioritas, yang berdasar pada prinsip investasi, yaitu memaksimalkan keuntungan.

\section{DAFTAR PUSTAKA}

Laudon, K. C. \& Laudon, J. (2006). Management Information Systems $\left(9^{\text {th }}\right.$ ed.). New Jersey: Pearson Prentice Hall.

Ward, J. \& Peppard, J. (2003). Strategic Planning for Information Systems (3 ${ }^{\text {rd }}$ ed.). Chicester: John Wiley \& Sons. 